\title{
ANALISA SISTEM KENDALI PUTARAN MOTOR DC MENGGUNAKAN SILICON CONTROLLED RECTIFIERS
}

\author{
Oleh \\ M. Khairudin, Efendi, N Purwantiningsih, W Irawan \\ Jurusan Pendidikan Teknik Elektro Fakultas Teknik \\ Universitas Negeri Yogyakarta \\ moh_khairudin@uny.ac.id
}

\begin{abstract}
ABSTRAK
Paper ini bertujuan untuk menganalisa rangkaian sistem kendali putaran motor menggunakan Silicon Controlled Rectifier (SCR) atau Thyristor. Eksperimen sistem kendali putaran motor ini menggunakan dua rangkaian yang berbeda. Rangkaian pertama menggunakan dua sumber, yaitu sumber tegangan DC $12 \mathrm{v}$ terhubung dengan motor universal secara seri dengan resistor dan SCR, sedangkan sumber tegangan DC variabel 0 sampai $1.5 \mathrm{v}$ dihubung paralel dengan kapasitor dan resistor. Rangkaian kedua menggunakan satu sumber tegangan AC $5 \mathrm{v}$ yang dihubungkan dengan saklar dan motor. Pada rangkaian kedua ini motor dihubungkan dengan potensio, SCR, dioda serta kapasitor yang dipasang paralel dengan sumber tegangan AC. Hasil eksperimen menunjukkan dalam rangkaian menggunakan sumber tegangan DC, motor DC akan berputar saat saklar S1 tertutup. Kondisi motor akan berputar lebih cepat ketika sumber tegangan variabel diatur lebih besar dari $0 \mathrm{v}$ sehingga arus gate $\mathrm{I}_{\mathrm{g}}$ lebih bear dari $400 \mathrm{~mA}$. Adapun Eksperimen dengan sumber tegangan AC, motor akan berputar dengan menambahkan dioda D3 dan pengaturan kecepatan melalui potensio meter Rv sampai posisi maksimum.
\end{abstract}

Kata kunci: analisa, motor DC, SCR, sistem kendali

\begin{abstract}
The objective of this study is to analyse the circuit of DC motor control system using Silicon Controlled Rectifier (SCR) or Thyristor. In this experiment the circuit of control system for the motor using two different circuits. The first circuit using two sources, the $12 \mathrm{v}$ DC voltage is connected to universal motor and series with a resistor and SCR, while the DC variable voltage source of 0 to $1.5 \mathrm{v}$ connected in parallel to the capacitor and resistor. The second circuit uses a single source of $5 \mathrm{~V}$ AC voltage connected to the switch and the motor. In the second circuit, the motor is connected to the potentio meter, SCR, diode and capacitor in parallel with the AC voltage source. The experimental results showed the circuit using a DC voltage source impacted the DC motor rotated after the switch S1 is closed then the motor rotated more faster when the variable voltage source is set greater than $0 \mathrm{v}$ then the gate current $I_{g}$ will be greater than $400 \mathrm{~mA}$. The AC voltage source rotated the DC motor, when inserted the diode D3 to control the motor rotation using potentio meter. The motor can be stopped by minimising Rv.
\end{abstract}

Keywords: analysis, control systems, DC motor. 


\section{PENDAHULUAN}

Teknologi dan ilmu pengetahuan yang semakin berkembang di zaman modern ini membawa dampak yang nyata baik di bidang informasi, pendidikan, ekonomi, bahkan teknologi. Di antara perkembangan teknologi yaitu pengendalian putaran motor menggunakan SCR atau thyristor. Kendali kecepatan merupakan cara merubah kecepatan ke nilai yang diperlukan guna melakukan suatu proses tertentu, ada perubahan alami dalam kecepatan karena beban pada poros. Kendali kecepatan dapat dilakukan baik secara manual dengan operator maupun secara otomatis.

Kendali kecepatan dapat melalui dua cara yaitu dengan mengubah jumlah masukan atau mengubah nilai frekuensi. Metode pertama dengan menambah jumlah masukan memiliki beberapa kelemahan selain harga yang tidak ekonomis juga jumlah kutub tidak bervariasi serta ukuran yang besar. Namun, kekurangan tersebut dapat diperbaiki menggunakan cara kedua yaitu mengubah nilai variasi frekuensi (Sindura dan Kartheek, 2013).

Dalam sistem kendali putaran motor DC secara elektronik, dapat dilakukan dengan menggunakan SCR. SCR memiliki tiga terminal yaitu anoda, katoda dan gate yang dapat digunakan dengan sumber masukan tegangan AC maupun DC. Tresino menggunakan nama thyristor sebagai nama lain SCR yang kemudian banyak diadobsi. Hal tersebut yang membuat IEC TC47 pada tahun 1960 mengumumkan bahwa nama thyristor menjadi nama lain SCR yang dapat diterima secara universal (Goce dan Slobodan, 2010).

SCR merupakan dua buah transistor dan memiliki tiga kaki yaitu anoda, katoda dan gate. Pengaturan motor DC menggunakan SCR melalui arus gate ( $\left.I_{g}\right)$, yaitu apabila arus gate $\left(\mathrm{I}_{\mathrm{g}}\right)$ nilainya dibawah holding current (Ih) maka SCR tersebut belum dapat mengalirkan arus dari anoda ke katoda sehingga motor belum berputar. Ketika $I_{g}$ melebihi nilai $\mathrm{I}_{\mathrm{h}}$ maka SCR akan mengalirkan arus yang menyebabkan motor berputar (Sugeng, 2010).

Beberapa keuntungan yang diperoleh saat menggunakan SCR dalam mengendalikan pengaturan beban putaran motor yaitu pengaturannya halus, kecilnya kerugian daya, sederhana dalam pemeliharaan. Beberapa faktor yang perlu diperhatikan untuk menjamin fungsi pengontrolan adalah permulaan berputar (starting), pemberhentian (stoping), membalikkan arah putaran (reserving), running, kendali kecepatan, pemeliharaan starting. Sistem kendali motor listrik menggunakan SCR, sumber tegangan AC sebagai tegangan anoda katoda. Adapun sumber DC dan beban resistor variabel dipasang seri dengan kaki gate sebagai terminal pengendali kaki gate tersebut. Ketika tegangan dan arus gate pada kaki SCR melebihi tegangan trigger 
breakdown, maka arus akan mengalir sehingga motor berputar. Jumlah putaran motor dapat sebanding dengan naik dan turunnya arus gate, sehingga SCR dapat digunakan untuk mengontrol kecepatan putar, torsi, dan daya dengan cara mengatur arus yang mengalir pada gate tersebut (Sapto, 2008).

Peralatan industri, rumah tangga hingga permainan anak sering menggunakan motor DC karena kemudahan dalam pemakaian. Namun, terdapat penurunan kecepatan putaran motor akibat pembebanan sehingga kecepatannya lambat dan tidak konstan. Kelemahan tersebut perlu diatasi dengan rangkaian pengendali agar kecepatan motor DC dapat berjalan sesuai dengan harapan. Kontroler yang dapat digunakan untuk mengatasi hal tersebut salah satunya yaitu dengan kontroler Proportional Integral Derivatif (PID), sehingga diperlukan pemodelan matematis motor DC untuk dapat diaplikasikan pada kendali menggunakan gambar rangkaian ekivalen (Waluyo dkk, 2013).

Motor DC merupakan peralatan yang banyak diaplikasikan di industri, membutuhkan variabel kecepatan serta beban untuk memudahkan dalam pengendalian (Snehlata dan Kompelli, 2014). Banyak aplikasi sistem penggerak listrik yang digunakan di industri membutuhkan kinerja yang tinggi, kehandalan serta kecepatan variabel untuk memudahkan dalam pengendalian. Kendali putaran motor bertujuan untuk menggerakkan motor pada kecepatan tertentu yang diwakili oleh sinyal yang diambil. Pengendalian motor DC dapat dilakukan secara elektronik maupun secara embedded system. Pada pengendalian putaran motor DC secara elektronik dapat menggunakan transistor, thyristor serta komponen lain untuk memudahkan pengendalian pada motor DC. Atul et.al (2012) telah melakukan eksplorasi pengendalian otomatis berbasis embedded system dapat memanfaatkan pulse width modulation (PWM) model loop tertutup. Loop tertutup (closed loop) merupakan sistem kendali yang aksi pengendaliannya dipengaruhi oleh sinyal keluaran (Erinofiardi dkk, 2012).

Perkembangan cepat teknologi menjadikan kendali kecepatan motor DC secara bertahap berpindah dari analog ke digital. Sistem kendali yang mengadopsi peralatan thyristor (yaitu silicon controlled thyristor, SCR) menggunakan prinsip pemicuan listrik untuk memasok listrik ke motor listrik yang dianggap lebih sederhana dan telah menggantikan sistem- sistem yang lama dan rumit seperti FD sistem generator-motor listrik (Liangzhong Jiang, 2009).

Paper ini membahas analisa sistem kendali putaran motor DC menggunakan SCR. Telah terdapat beberapa penelitian tentang kendali elektronik untuk motor DC akan tertapi masih sedikit yang memaparkan analisa hasil sistem kendali motor DC menggunakan SCR. 


\section{METODE PENELITIAN}

Rangkaian sistem kendali putaran motor menggunakan SCR dirancang dengan dua rangkaian yang berbeda. Pertama menggunakan sumber tegangan DC dan yang kedua menggunakan sumber tegangan AC. Perancangan dan penyusunan sistem kendali putaran motor menggunakan SCR saat rangkaian menggunakan sumber DC terdiri dari DC $12 \mathrm{v}$ yang dihubungkan dengan motor universal diseri dengan resistor $1 \mathrm{k} \Omega$ dan SCR. Adapun DC variabel 0 hingga $1.5 \mathrm{v}$ dihubungkan paralel dengan kapasitor $1 \mu \mathrm{F}$ dan resistor $1 \mathrm{k} \Omega$. Selanjutnya rangkaian paralel tersebut dihubungkan dengan saklar. Gambar 1 merupakan rangkaian kendali putaran motor menggunakan SCR dengan sumber tegangan DC.

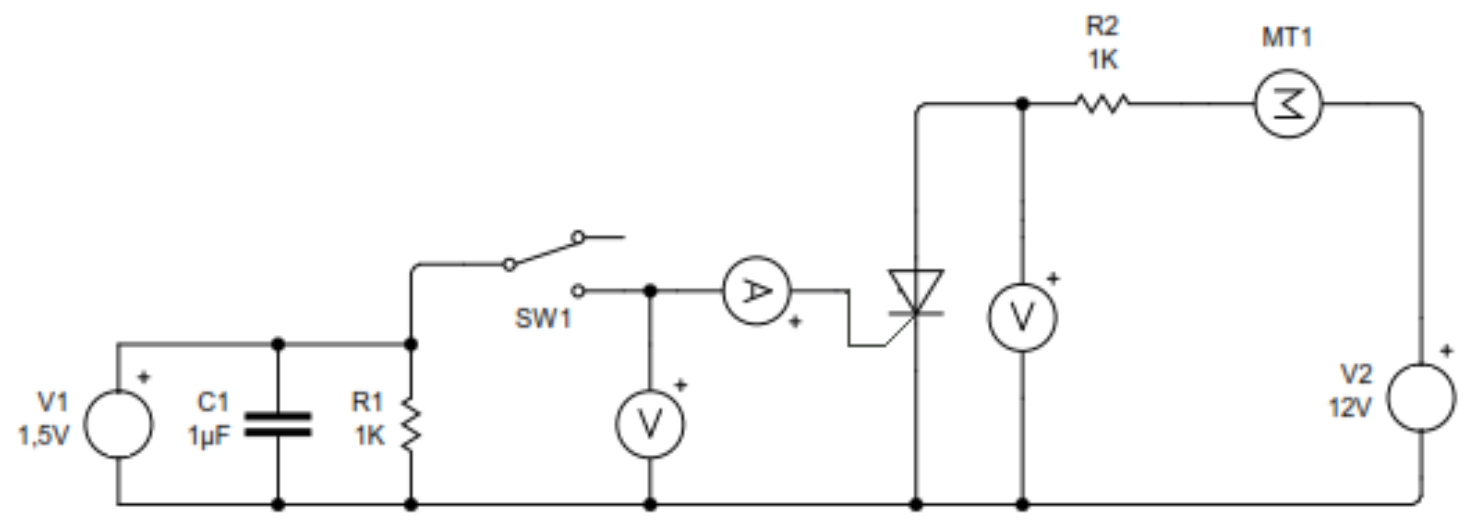

Gambar 1. Rangkaian pengendali putaran motor menggunakan SCR sumber DC

Perancangan dan penyusunan sistem kendali putaran motor menggunakan SCR pada percobaan kedua menggunakan sumber tegangan AC dihubungkan dengan saklar dan motor. Selanjutnya motor dihubungkan dengan potensio, SCR, dioda serta kapasitor $1 \mu \mathrm{F}$ yang dipasang paralel dengan sumber tegangan AC. Gambar 2 menunjukkan rangkaian kendali putaran motor menggunakan SCR dengan sumber tegangan AC.

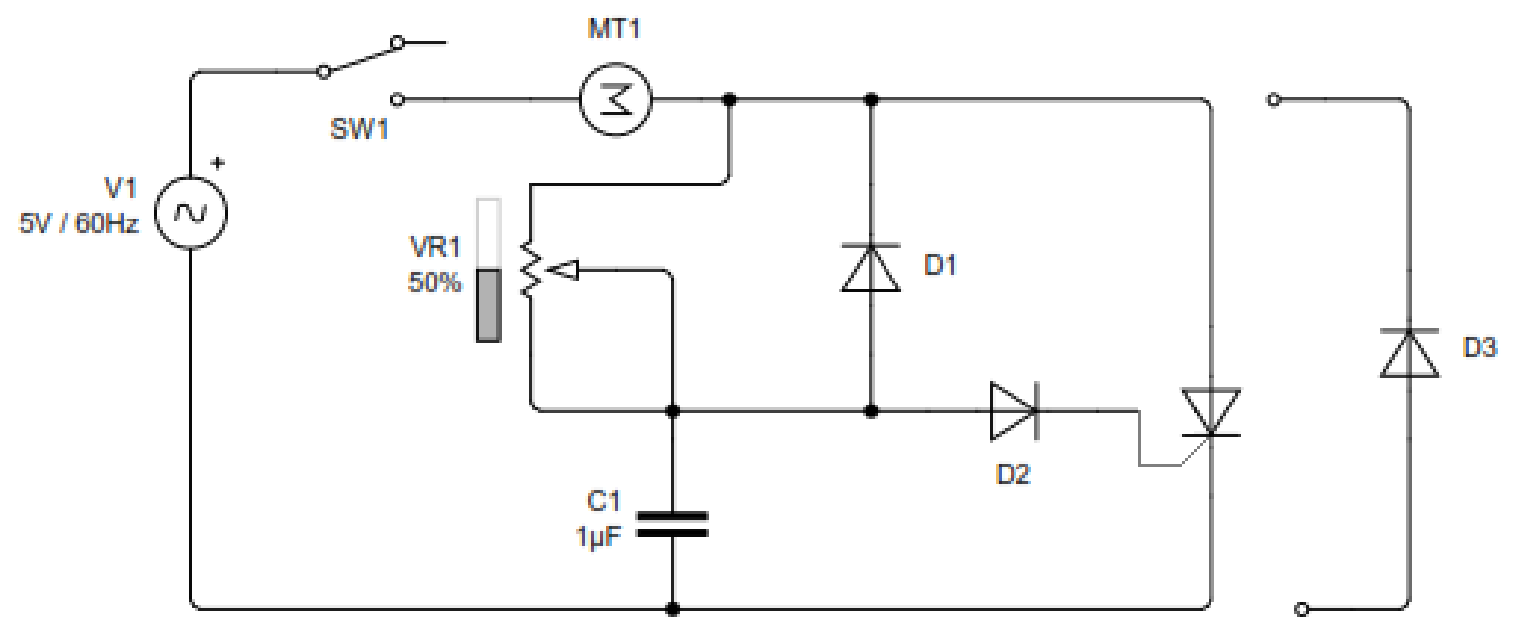

Gambar 2. Rangkaian pengendali putaran motor menggunakan SCR sumber AC 
Rangkaian kendali putaran motor menggunakan SCR dirancang dengan rangkaian elektronik melalui proses penerimaan inputan dari saklar untuk rangkaian pertama dengan sumber tegangan DC dan potensio meter pada rangkaian 2 dengan sumber tegangan AC. Rangkaian elektronik kendali putaran motor menggunakan SCR ini dikembangkan dengan (1) Rangkaian Catu Daya 12 volt, 0 hingga $1.5 \mathrm{v}$ sebagai tegangan variabel untuk sumber tegangan DC dan 5 volt untuk sumber tegangan AC, (2) rangkaian inputan, (3) rangkaian kendali. Secara elektronik Gambar 3 menunjukkan rangkaian pada eksperimen ini.

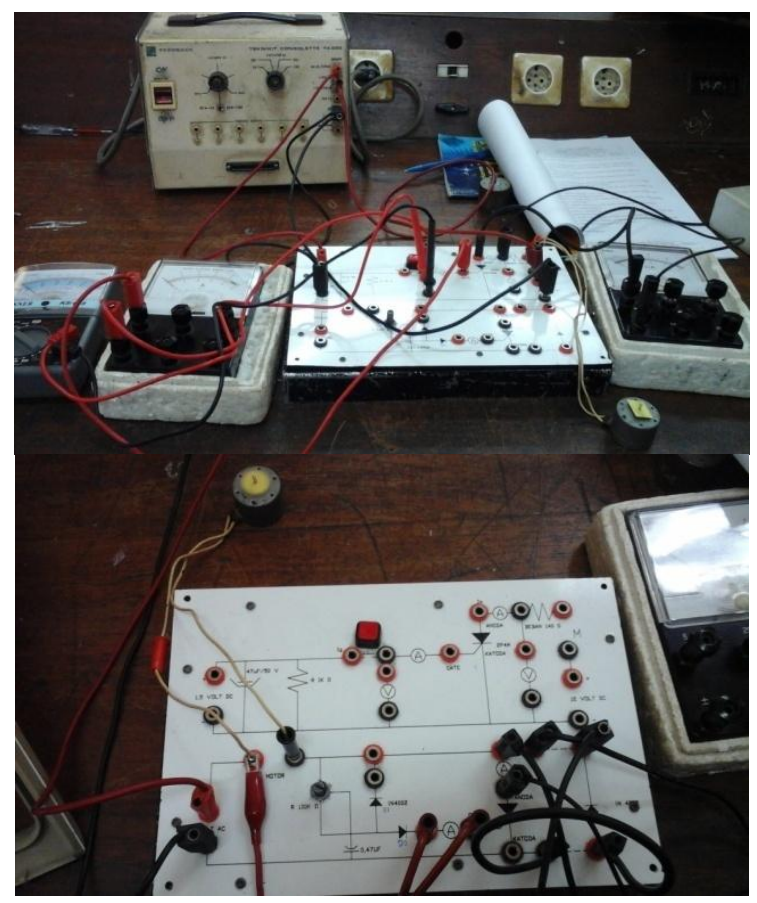

Gambar 3. Rangkaian sistem kendali putaran motor menggunakan SCR.

\section{HASIL DAN PEMBAHASAN}

Percobaan dimulai dengan melakukan eksperimen rangkaian sumber tegangan DC. Dalam eksperimen digunakan motor dengan spesifikasi 12V/1A dan menggunakan saklar push button untuk menyulut arus pada kaki gate SCR. Adapun SCR menjadi saklar untuk meneruskan tegangan sehingga motor dapat berputar. Langkah awal percobaan yaitu merangkai rangkaian seperti rangkaian pada Gambar 1. Rangkaian 1 dikatakan benar jika saklar push button ditekan sehingga ada arus yang memicu kaki gate untuk mengaktifkan SCR. Setelah SCR aktif sebagai saklar elektronik maka akan meneruskan tegangan ke motor sehingga motor dapat bekerja (berputar).

Selanjutnya melakukan pengukuran tegangan anoda dan katoda pada $\operatorname{SCR}\left(\mathrm{V}_{\mathrm{a}-\mathrm{k}}\right)$. 
Percobaan pengukuran tegangan anoda-katoda dilakukan sebanyak dua puluh percobaan. Setelah pengujian tegangan anoda-katoda kemudian melakukan percobaan terhadap tegangan pada gate dan katoda $\left(\mathrm{V}_{\mathrm{g}-\mathrm{k}}\right)$. Pada percobaan ini kondisi saklar S1 dalam keadaan terbuka (off). Tabel 1 berikut ini merupakan hasil pengujian $V_{a-k}$.

\begin{tabular}{cccc}
\multicolumn{4}{c}{ Tabel 1. Hasil Pengukuran $\mathrm{V}_{\mathrm{a}-\mathrm{k}}$ dan $\mathrm{V}_{\mathrm{g}-\mathrm{k}}$} \\
\hline \multicolumn{3}{c}{$\mathrm{V}_{\mathrm{a}-\mathrm{k}}$} & \multicolumn{3}{c}{$\mathrm{V}_{\mathrm{g}-\mathrm{k}}$} \\
Percobaan & Hasil & Percobaan & Hasil \\
\hline 1 & $4.6 \mathrm{~V}$ & 1 & $0.6 \mathrm{~V}$ \\
2 & $4.7 \mathrm{~V}$ & 2 & $0.6 \mathrm{~V}$ \\
3 & $4.6 \mathrm{~V}$ & 3 & $0.6 \mathrm{~V}$ \\
4 & $4.6 \mathrm{~V}$ & 4 & $0.5 \mathrm{~V}$ \\
5 & $4.5 \mathrm{~V}$ & 5 & $0.6 \mathrm{~V}$ \\
6 & $4.5 \mathrm{~V}$ & 6 & $0.5 \mathrm{~V}$ \\
7 & $4.7 \mathrm{~V}$ & 7 & $0.6 \mathrm{~V}$ \\
8 & $4.6 \mathrm{~V}$ & 8 & $0.6 \mathrm{~V}$ \\
9 & $4.5 \mathrm{~V}$ & 9 & $0.7 \mathrm{~V}$ \\
10 & $4.6 \mathrm{~V}$ & 10 & $0.6 \mathrm{~V}$ \\
11 & $4.5 \mathrm{~V}$ & 11 & $0.6 \mathrm{~V}$ \\
12 & $4.6 \mathrm{~V}$ & 12 & $0.7 \mathrm{~V}$ \\
13 & $4.7 \mathrm{~V}$ & 13 & $0.6 \mathrm{~V}$ \\
14 & $4,5 \mathrm{~V}$ & 14 & $0.6 \mathrm{~V}$ \\
15 & $4.5 \mathrm{~V}$ & 15 & $0.6 \mathrm{~V}$ \\
16 & $4.5 \mathrm{~V}$ & 16 & $0.6 \mathrm{~V}$ \\
17 & $4.5 \mathrm{~V}$ & 17 & $0.7 \mathrm{~V}$ \\
18 & $4.5 \mathrm{~V}$ & 18 & $0.6 \mathrm{~V}$ \\
19 & $4.7 \mathrm{~V}$ & 19 & $0.6 \mathrm{~V}$ \\
20 & $4.5 \mathrm{~V}$ & 20 & $0.6 \mathrm{~V}$ \\
\hline & & &
\end{tabular}

Tabel 1 menunjukan hasil pengujian tegangan anoda-katoda dan tegangan gatekatoda. Hasil percobaan menunjukan tegangan rata-rata pada anoda-katoda adalah 4.6 V. Hal ini berarti terdapat konsistensi besar tegangan $\mathrm{V}_{\mathrm{a}-\mathrm{k}}$ sehingga dapat dikatakan bahwa rangkaian dapat bekerja sesuai dengan standar. Hasil pengukuran pada tegangan gatekatoda menunjukan tegangan rata- rata $\mathrm{V}_{\mathrm{g}-\mathrm{k}} 0.6 \mathrm{~V}$. Hal ini menunjukan bahwa terdapat besar tegangan yang sama dalam setiap pengujian sehingga rangkaian dapat bekerja sesuai dengan standar.

Pada percobaan ini kondisi saklar S1 dalam keadaan terbuka. Kondisi motor belum 
berputar karena meskipun sudah mendapatkan tegangan 5v namun saklar S1 dalam keadaan terbuka atau off. Sehingga belum ada arus yang sampai ke motor atau dengan kata lain belum ada pemicu motor untuk bergerak.

Percobaan berikutnya yaitu percobaan pada kondisi saklar S1 dalam keadaan tertutup (on). Saklar S1 dalam kondisi tertutup bertujuan untuk menguhungkan rangkaian dengan sumber tegangan variable 0 hingga $1,5 \mathrm{~V}$. Pada percobaan ini motor berputar dan arus yang mengalir pada gate $\left(I_{\mathrm{g}}\right)$ SCR maksimum karena mendapat suplai tegangan variable 0 hingga $1.5 \mathrm{~V}$. Hasil percobaan pengukuran nilai arus yang mengalir pada gate $\left(\mathrm{I}_{\mathrm{g}}\right)$ dapat dilihat pada Tabel 2 berikut.

Tabel 2. Hasil Pengukuran pada Ig

\begin{tabular}{cc}
\hline Percobaan & Hasil \\
\hline 1 & $420 \mathrm{~mA}$ \\
2 & $420 \mathrm{~mA}$ \\
3 & $430 \mathrm{~mA}$ \\
4 & $420 \mathrm{~mA}$ \\
5 & $430 \mathrm{~mA}$ \\
6 & $400 \mathrm{~mA}$ \\
7 & $430 \mathrm{~mA}$ \\
8 & $400 \mathrm{~mA}$ \\
9 & $420 \mathrm{~mA}$ \\
10 & $430 \mathrm{~mA}$ \\
11 & $400 \mathrm{~mA}$ \\
12 & $400 \mathrm{~mA}$ \\
13 & $420 \mathrm{~mA}$ \\
14 & $420 \mathrm{~mA}$ \\
15 & $400 \mathrm{~mA}$ \\
16 & $420 \mathrm{~mA}$ \\
17 & $420 \mathrm{~mA}$ \\
18 & $400 \mathrm{~mA}$ \\
19 & $430 \mathrm{~mA}$ \\
20 & $400 \mathrm{~mA}$ \\
\hline
\end{tabular}

Tabel 2 menunjukan hasil percobaan pengukuran terhadap nilai arus yang mengalir pada gate $\left(\mathrm{I}_{\mathrm{g}}\right)$ ketika saklar S1 dalam kondisi tertutup. Hasil rata- rata nilai arus yang mengalir pada gate $\left(I_{g}\right)$ ini menunjukan nilai 415,5 mA. Sehingga motor dapat berputar karena terdapat pemicuan arus gate $\left(\mathrm{I}_{\mathrm{g}}\right)$ pada $\mathrm{SCR}$ ini.

Jarum penunjuk pada ampere meter bergerak kearah kanan. Pergerakan jarum penunjuk pada ampere meter mengindikasikan terdapat arus yang mengalir pada gate yang menyebabkan motor dapat berputar. Arah gerak ampere meter saat tegangan dibuat 0 VDC juga menunjukan posisi yang tetap yaitu kearah kanan (terdapat arus). Tahap selanjutnya yaitu mengubah-ubah nilai tegangan variabel hingga mencapai nilai minimum atau sama dengan nol. Berdasarkan percobaan mengubah nilai tegangan variabel jarum penunjuk pada ampere meter tetap menunjuk sebuah nilai arus. Hal tersebut sesuai 
dengan prinsip SCR secara umum yaitu ketika SCR dipicu dengan tegangan DC maka SCR akan selalu on walaupun tegangan DC sama dengan nol. SCR dapat dimatikan hanya apabila diberi rangkaian dioda komutasi.

Hasil percobaan ini menunjukan arus $I_{g}$ sekitar $420 \mathrm{~mA}$. Arus $I_{g}$ dapat mengakibatkan motor berputar. Motor dapat berputar karena adanya pacuan dari saklar S1 yang membuat arus mengalir dari sumber ke motor atau beban. Untuk arah ampere meter yaitu ke arah kanan, mengingat arus yang dihasilkan atau yang sampai di motor adalah positif.

Percobaan selanjutnya adalah membuka kembali saklar (OFF), dan mengamati kondisi motor. Langkah selanjutnya adalah mengamati kembali $\mathrm{V}_{\mathrm{a}-\mathrm{k}}$ pada SCR. Hasil tegangan $\mathrm{V}_{\mathrm{a}-\mathrm{k}}$ setelah saklar terbuka (OFF) dapat dilihat pada Tabel 3 berikut.

Tabel 3. Pengujian $\mathrm{V}_{\mathrm{a}-\mathrm{k}}$ saat saklar kembali dibuka

\begin{tabular}{cc}
\hline Percobaan & Hasil \\
\hline 1 & $4,6 \mathrm{VDC}$ \\
2 & $4,6 \mathrm{VDC}$ \\
3 & $4,6 \mathrm{VDC}$ \\
4 & $4,6 \mathrm{VDC}$ \\
5 & $4,6 \mathrm{VDC}$ \\
6 & $4,6 \mathrm{VDC}$ \\
7 & $4,5 \mathrm{VDC}$ \\
8 & $4,6 \mathrm{VDC}$ \\
9 & $4,6 \mathrm{VDC}$ \\
10 & $4,5 \mathrm{VDC}$ \\
\hline
\end{tabular}

Tabel 3 menunjukan hasil rata- rata tegangan $\mathrm{V}_{\mathrm{a}-\mathrm{k}}$ sebesar 4,6 VDC. Hal ini menunjukan kesamaan pada Tabel 1 walaupun dalam keadaan yang berbeda yaitu saklar S1 telah terbuka (OFF).

Langkah selanjutnya adalah mengamati kembali keadaan tegangan $\mathrm{V}_{\mathrm{g}-\mathrm{k}}$ agar diperoleh perbandingan antara tegangan $\mathrm{V}_{\mathrm{g}-\mathrm{k}}$ saat saklar (tertutup) $\mathrm{ON}$ dan saat saklar (terbuka) OFF. Hasil pengamatan tegangan $\mathrm{V}_{\mathrm{g}-\mathrm{k}}$ dapat dilihat pada Tabel 4 berikut ini.

Tabel 4. Pengujian $\mathrm{V}_{\mathrm{g}-\mathrm{k}}$ saat saklar kembali dibuka

\begin{tabular}{cc}
\hline Percobaan & Hasil \\
\hline 1 & 0,4 VDC \\
2 & 0,5 VDC \\
3 & 0,5 VDC \\
4 & 0,6 VDC \\
5 & 0,6 VDC \\
6 & 0,7 VDC \\
7 & 0,7 VDC \\
8 & 0,7 VDC \\
9 & 0,8 VDC \\
\hline
\end{tabular}




\begin{tabular}{ll}
\hline 10 & $0,9 \mathrm{VDC}$ \\
\hline
\end{tabular}

Tabel 4 menunjukan hasil pengukuran tegangan $\mathrm{V}_{\mathrm{g}-\mathrm{k}}$ setelah saklar dalam keadaan terbuka (OFF). Rata - rata dari pengujian ini adalah sebesar 0,6 VDC. Meskipun hasil berbeda dengan Tabel 2 namun hasil rata- rata tetap menunjukan kesamaan nilai tegangan yaitu 0,6 VDC dengan pengujian dalam keadaan saklar terbuka (OFF). Hasil pada Tabel 3 dan 4 membuktikan teori SCR bahwa saat SCR aktif maka akan tetap aktif walaupun arus gate sudah tidak mendapat picuan (saklar terbuka, off). Terbukti bahwa tegangan $\mathrm{V}_{\mathrm{a}-\mathrm{k}}$ dan $\mathrm{V}_{\mathrm{g}-\mathrm{k}}$ setelah dipicu dan sebelum dipicu menghasilkan hasil tegangan yang sama. Selain itu kondisi motor juga tetap berputar dan arus gate sama dengan percobaan saat saklar sudah tertutup (off).

Langkah selanjutnya yaitu melakukan pengujian arus $I_{g}$ saat saklar kembali dibuka (off). Hasil pengukuran dapat dilihat pada Tabel 5 berikut.

Tabel 6. Pengujian arus gate saat saklar kembali dibuka

\begin{tabular}{cc}
\hline Percobaan & Hasil \\
\hline 1 & $420 \mathrm{~mA}$ \\
2 & $420 \mathrm{~mA}$ \\
3 & $420 \mathrm{~mA}$ \\
4 & $420 \mathrm{~mA}$ \\
5 & $400 \mathrm{~mA}$ \\
6 & $400 \mathrm{~mA}$ \\
7 & $400 \mathrm{~mA}$ \\
8 & $400 \mathrm{~mA}$ \\
9 & $420 \mathrm{~mA}$ \\
10 & $420 \mathrm{Ma}$ \\
\hline
\end{tabular}

Eksperimen kendali putaran motor dengan SCR tegangan DC telah sesuai teori SCR. Kondisi SCR setelah dipicu maka aktif dan selanjutnya akan tetap aktif. Setelah ekserimen kendali putaran motor dengan SCR tegangan DC kemudian dilanjutkan dengan percobaan kendali putaran Motor dengan SCR dengan tegangan AC dan rangkaian yang berbeda.

Pada rangkaian 2, kendali motor menggunakan resistor variable (Rv) untuk mengatur kecepatan motor, sedangkan SCR menjadi saklar untuk meneruskan tegangan sehingga motor dapat berputar. SCR akan bekerja apabila pada kaki gate diberi arus picu. Eksperimen dilakukan untuk mengetahui cara kerja SCR saat aktif pada teganggan AC, mengetahui arus picu pada gate SCR yang berfungsi sebagai saklar. Rangkaian 2 
dikatakan benar jika rangkaian 2 yaitu SCR sebagai saklar meneruskan tegangan yang berasal dari diode 2 sehingga motor dapat menyala. Sedangkan untuk mengaktifkan SCR maka saklar toggle harus dalam kondisi ON sehingga ada arus yang memicu kaki gate untuk mengaktifkan SCR, karena pada teganggan AC SCR akan off apabila tidak ada arus pada kaki gate.

Pada percobaan pengendali putaran motor dengan SCR bersumber AC ini putaran motor sanngat bergantung pada besar potensio meter atau hambatan. Semakin besar potensio meter maka putaran motor semakin melambat, dengan kata lain motor dapat dihentikan atau dimatikan dengan cara memaksimalkan potensio meter, namun hal yang berbeda jika D3 dipasang. Saat D3 dipasang motor akan semakin cepat jika potensio meter dimaksimalkan dengan kata lain motor dapat dimatikan atau dihentikan dengan mengecilkan potensio meter karena pada D3 terjadi rangkaian komutasi sehingga tegangan pada SCR akan membalik ke motor..

Saat Diode 3 (D3) belum terpasang :dengan mengatur potensiometer (Rv) perlahan- lahan dari minimum ke maksimum. Putaran motor semakin lambat, karena dapat diketahui bahwa hambatan berbanding terbalik dengan arus, maka semakin besar hambatan yang diberikan maka semakin kecil pula arus yang dihasilkan dengan kata lain semakin besar potensio meter semakin lambat pula putaran motornya.

Gambar 4 menunjukan gelombang putaran motor pada kondisi maksimum(puncak) diakibatkan kondisi Resisitor Variable (RV) dalam kondisi minimum dengan kata lain hampir sama dengan nol sehingga arus motor maksimal.

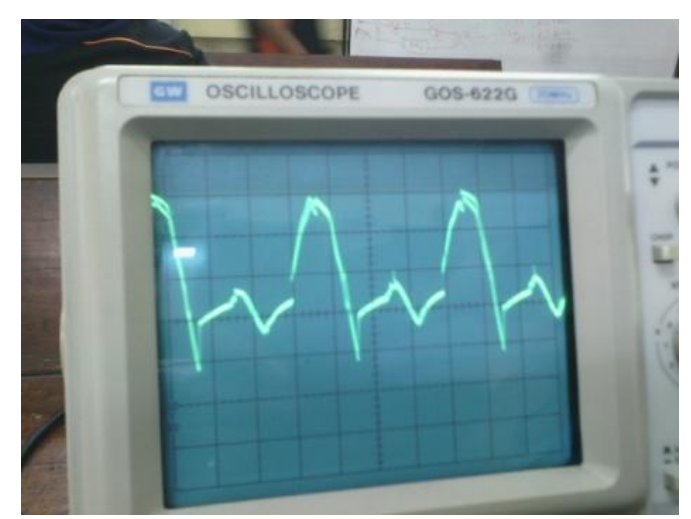

Gambar 4. Gelombang saat potensiometer diperbesar

Saat Diode 3 (D3) sudah terpasang, maka dengan mengatur potensiometer $\left(\mathrm{R}_{\mathrm{V}}\right)$ perlahan- lahan dari minimum ke maksimum. Putaran motor semakin cepat, oleh karena terdapat D3 yang menjadi rangkaian komutasi, sehingga semakin besar hambatan yang 
diberikan maka semakin besar pula arus yang dihasilkan. Semakin besar potensio meter semakin besar pula putaran motor.

\section{SIMPULAN}

Berdasarkan hasil dan pembahasan dapat disimpulkan: (1) Pada saat percobaan sistem kendali putaran motor menggunakan SCR dengan sumber tegangan DC dan sumber tegangan AC. Pada saat percobaan menggunakan sumber tegangan DC, motor akan berputar apabila saklar dipicu. Kecepatan putaran motor dipengaruhi besar dan kecilnya tegangan variabel. Semakin besar tegangan variabel, maka motor akan berputar semakin cepat. (2) Pengendalian putaran motor dengan SCR tegangan AC, saat dioda D3 belum terpasang terjadi kondisi bila semakin besar nilai potensio meter maka semakin kecil arus dan akan menyebabkan motor melambat serta bentuk gelombang mengecil. Sedangkan saat dioda D3 dipasang, maka akan berbanding terbalik dengan saat D3 belum terpasang, yaitu saat potensio maksimal maka gerakan motor juga maksimal. Pada kondisi ini, motor dapat dimatikan dengan cara meminimalkan potensio meter.

\section{DAFTAR PUSTAKA}

Atul K. Dewangan, Nibbedita Chakraborty, Sashi Shukla, Vinod Yadu. 2012. PWM Based Automatic Closed Loop Control of DC Motor. International Journal of Engineering Trends and Technology, Vol. 3, Issue , 2012.

Erinofiardi, Nurul Iman S., Redi. Penggunaan PLC dalam Pengontrolan Temperatur, Simulasi pada Prototype Ruangan. Jurnal Mekanikal, ISSN: 2086-3403, Vol. 3, No. 2, Juli 2012: 261-268.

Goce L. Arsov and Slobodan Mirčevski (2010). The Sixth Decade of the Thyristor. International Journal of Electonics,Vol. 14, N0. 1, June 2010.

Liangzhong Jiang (2009). Sign of the Closed Loop Speed Control System for DC Motor. International Journal of Computer and Information Science,Vol. 02, N0. 1, February 2009.

Sapto Haryoko. 2012. Sistem Pengendali Motor-Motor Listrik Dengan SCR (Silicon Controlled Rectifier). Jurnal Media Elektrik, Vol. 3, No. 2, desember 2008.

Sindura, B. S. Kartheek, B. N.. 2013. Speed Control of Induction Motor Using Cycloconverter. International Journal of Engineering Trends and Technology (IJETY), Vol. 4, Issue 4, April 2013.

Snehlata Sanjay Thakare and Santosh Kompelli. 2014. Design and Implementation of DC 
Motor Speed Control Based On Pic Microcontroller. International Journal Of Engineering And Computer Sciene ISSN: 2319-7242 Vol. 3, Issue 9, September, 2014 Page No. 8075-8079.

Sugeng A. Karim. 2010. Aplikasi Silicon Control Reactifier (SCR) Pada Pengontrolan Motor Listrik. Jurnal Media Elektrik Vol 5. No. 1 Juni 2010.

Waluyo, Aditya Fitriansyah, Syahrial. 2013. Analisis Penalaan Kontrol PID pada Simulasi Kendali Kecepatan Putaran Motor DC Berbeban menggunakan Metode Heuristik. Jurnal Teknik Elektrik, Teknik Telekomunikasi \& Teknik Elektronika, Vol. 1, No. 2, Juli- Desember 2013. 